\title{
The global hepatitis delta virus (HDV) epidemic: what gaps to address in order to mount a public health response?
}

Tomoyuki Hayashi ${ }^{12^{*}}$ D, Yumie Takeshita ${ }^{1,2}$, Yvan J.-F. Hutin ${ }^{1}$, Hande Harmanci ${ }^{1}$, Philippa Easterbrook ${ }^{1}$, Sarah Hess ${ }^{1}$, Judith van Holten ${ }^{1}$, Ena Oghenekaro Oru', Shuichi Kaneko², Cihan Yurdaydinn ${ }^{3,4}$ and Marc Bulterys ${ }^{1}$

\begin{abstract}
Background: Co-infection between hepatitis B virus (HBV) and hepatitis delta virus (HDV) causes the severest chronic hepatitis and is associated with a high risk of cirrhosis and hepatocellular carcinoma (HCC). The Global Health Sector Strategy on Viral Hepatitis called for the elimination of hepatitis (-65\% mortality and -90\% incidence) by 2030. Our aims were to summarize key points of knowledge and to identify the gaps that need to be addressed to mount a public health response to HDV.
\end{abstract}

Methods: We performed a current literature review in terms of epidemiology by WHO regions, genotypes distribution and their pathogenicity, factors associated with HDV infection, mortality due to HDV infection, testing strategies and treatment.

Results: Prevalence of infection and genotypes are heterogeneous distributed, with highest prevalence in foci around the Mediterranean, in the Middle East, and in Central, Northern Asia and Eastern Asia. Persons who inject drugs (PWID) and migrants from highly endemic areas are highly affected. While antibody detection tests are available, HDV RNA tests of current infection are not standardized nor widely available. The few therapeutic options, including lofartinib, are not widely available; however several new and promising agents have entered clinical trials.

Conclusion: HDV infection is an poorly known cause of chronic liver disease. To mount a public health response, we need a better description of the HDV epidemic, standardized testing strategies and better treatment options.

Keywords: Hepatitis delta, HDV, Hepatitis B virus, Prevalence, Superinfection, Novel therapeutic strategies, Cirrhosis, Hepatocellular carcinoma

\section{Background}

Of the viruses causing hepatitis, Hepatitis delta Virus (HDV) is unique in that it needs the helper function of Hepatitis B Virus (HBV) to infect hepatocytes [1]. The World Health Organization (WHO) estimates that in

\footnotetext{
*Correspondence: hayasix0917@gmail.com

'Global Hepatitis Programme, World Health Organization, Geneva, Switzerland

2Department of Gastroenterology, Kanazawa University and WHO Collaborating Center for Chronic Hepatitis and Liver Cancer, Kanazawa, Ishikawa, Japan

Full list of author information is available at the end of the article
}

2015, 257 million people (3.5\% of the world's population) were infected with HBV [2]. However, WHO does not have estimates of prevalence or mortality for HDV. Co-infection of an HBV infected person with HDV worsens the outcome, with higher rates of cirrhosis and hepatocellular carcinoma. Most published reviews quote $5 \%$ as an estimate of the prevalence of HDV coinfection among persons with HBV infection (about 13 million persons worldwide) [3], mostly in high endemicity foci or among immigrants from highly endemic regions [4].

(c) The Author(s). 2021 Open Access This article is licensed under a Creative Commons Attribution 4.0 International License, which permits use, sharing, adaptation, distribution and reproduction in any medium or format, as long as you give appropriate credit to the original author(s) and the source, provide a link to the Creative Commons licence, and indicate if changes were made. The images or other third party material in this article are included in the article's Creative Commons licence, unless indicated otherwise in a credit line to the material. If material is not included in the article's Creative Commons licence and your intended use is not permitted by statutory regulation or exceeds the permitted use, you will need to obtain permission directly from the copyright holder. To view a copy of this licence, visit http://creativecommons.org/licenses/by/4.0/ The Creative Commons Public Domain Dedication waiver (http://creativecommons.org/publicdomain/zero/1.0/) applies to the data made available in this article, unless otherwise stated in a credit line to the data. 
In 2016, the Global Health Sector Strategy (GHSS) on Viral Hepatitis [5] called for the elimination of hepatitis $(-65 \%$ mortality and $-90 \%$ incidence) by 2030. The prevention components of the GHSS (e.g., HBV immunization, blood and injection safety programmes) will prevent HBV infection and thus HDV infection. However, the GHSS provides limited solutions for HDV infection from a testing and treatment perspective. In recent two meta-analyses, the global prevalence had been estimated to be $0.8-0.98 \%$ in the general population, and $13-14 \%$ in the HBsAgpositive population, which corresponds to around 60 million infections globally $[6,7]$.

A number of professional associations [8-12] address hepatitis D in their care and treatment guidelines (Table 1). Several reviews summarized the landscape in epidemiology [13, 14], testing [15], or treatment [16]. However, these did not address HDV care from a public health perspective. We therefore performed a current literature review in terms of epidemiology by WHO regions, genotypes distribution and their pathogenicity, factors associated with HDV infection, mortality due to HDV infection, testing strategies and treatment. Our aims were to summarize key points of knowledge and to identify the gaps that need to be addressed to mount a public health response to HDV.

\section{Epidemiology by WHO regions}

Recent review estimated 12 million people worldwide have experienced HDV infection. The geographic distribution of HDV infection is heterogeneous [17]. Among HBV infected persons, HDV infection is particularly common in Central and West Africa, Central and Northern Asia, Viet Nam, Mongolia, Pakistan, Japan, the Taiwan province of China, Pacific Islands (Kiribati, Nauru), the Middle East, Eastern Europe (e.g., Turkey), South America (the Amazone basin), and Greenland [8, 18] (Fig. 1).

\section{Africa}

In a 2017 systematic review, HDV antibody (anti-HDV) prevalence among HBV-infected persons varied from $26 \%$ in Central Africa, $7 \%$ in West Africa, to only $0.05 \%$ in Eastern and Southern Africa. High-prevalence spots were reported in Gabon $(45 \%, 2015)$, Democratic Republic of the Congo $(26 \%, 2017)$, Mauritania $(19 \%, 2009)$, Cameroon $(14-35 \%, 2011)$ and Nigeria $(5 \%, 2014)$ in the general HBV infected population. Among HIV-HBV coinfected persons, high prevalence spots were reported in Guinea-Bissau $(25 \%, 2011)$, Cameroon $(12 \%, 2010)$ and Nigeria $(7 \%, 2004)[14]$.

\section{The Americas}

HBV mostly affects Indigenous Populations in the Americas. In the Amazon region of North Brazil, in
2003-2009, anti-HDV prevalence was $29 \%$. among HBV infected persons $[19,20]$. Anti-HDV prevalence in indigenous populations with HBV infection was 39\% of Peru, $13 \%$ in Brazil, $8 \%$ in Colombia, and $4-6 \%$ in Venezuela [21]. In the United States, anti-HDV prevalence among HBV-infected persons was around 3\% [22] between 2012 and 2016. Advanced fibrosis was associated with high HDV viral load in the western Amazon Basin of Brazil [23]. From 2008 to 2014, agestandardized mortality rates due to HDV were much higher in the North region of 2.2 per million compared to all regions of 0.28 per million [19].

\section{Eastern Mediterranean}

A 2010, a systematic review estimated that anti-HDV prevalence was $15 \%$ in persons with HBV infection (pooled prevalence: 25\% in Sudan, 18\% in Pakistan, 16\% in Tunisia, 11\% in Egypt, 7\% in Saudi Arabia, 5\% in Iran, and $2 \%$ in Yemen) [13]. In Pakistan, there is a high prevalence belt in the rural Sindh province [24]. In other countries, one study was available that reported $29 \%$ in Afghanistan, $17 \%$ in Somalia, $2 \%$ in Jordan, $2 \%$ in Djibouti, and $0.9 \%$ in Lebanon [14].

\section{Europe}

In Europe, areas reporting high prevalence of anti-HVD among HBV infected persons include Romania (23\%, 2015) [25], Eastern Turkey (15\%, 2012-2014 [26], higher than in western Turkey (3\%) [27], Yakutia, Siberia, Russia (18-20\%, 1996-1998) [28], and Greenland, among Inuits $[29,30](6 \%, 2011)$ [31]. In Austria, Belgium, Bulgaria, Czech Republic, Croatia, France, Greece, Ireland, Poland, and Switzerland, HDV is uncommon [32].

\section{South-East Asia}

In Bangladesh, $22 \%$ of $\mathrm{HBV}$ infected persons were antiHDV positive in 2003 [33]. In New Delhi, India, a 11\% anti-HBV prevalence was reported in HBV infected persons in 2005 [34]. In others areas with high prevalence of HBV such as Indonesia [35] and Thailand [36], HDV is uncommon [24].

\section{Western Pacific}

In Mongolia, where hepatocellular carcinoma (HCC) is the most common cancer (annual rate: 54.1 cases per 100,000 people) [37], anti-HDV prevalence among HBV infected perons was 45\% in 2013 [37] (60\% in 2017 when using a novel quantitative microarray antibody capture assay) [38]. In China, $4 \%$ of persons with HBV infection were anti-HDV positive in Inner Mongolia, Xinjiang and Tibet, where ethnic minorities live [39]. The Taiwan province of China was endemic for $\mathrm{HBV}$, but following immunization, the prevalence of $\mathrm{HBV}$ and HDV 


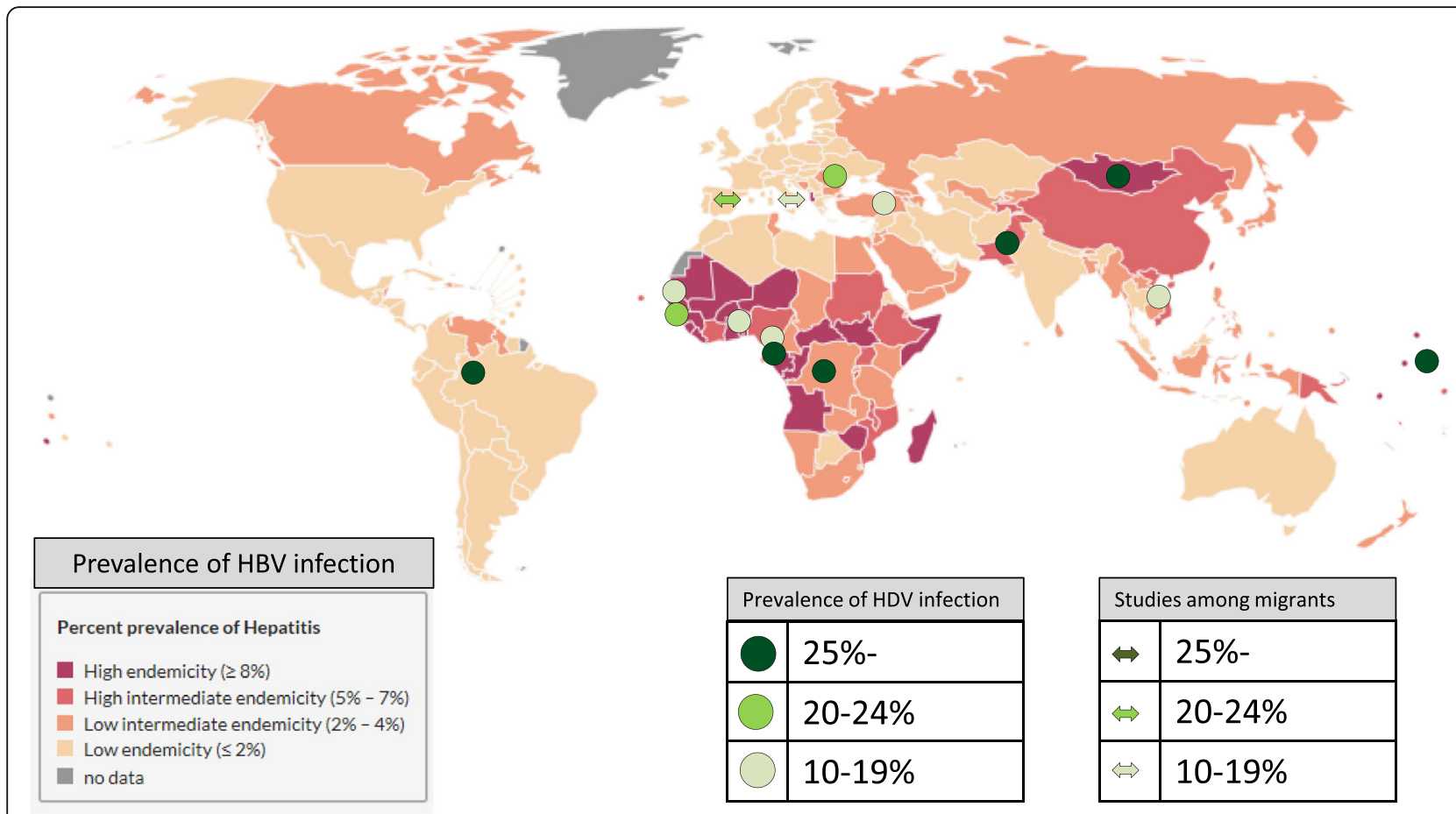

Fig. 1 Geographical location of studies reporting high prevalence of HDV infection among HBV infected people, in all ages, worldwide, 2008-2017

infection decreased. However, anti-HDV was more common in the south than in the north $(6 \%$ vs $2 \%)$ [40]. In Japan, HDV is highly prevalent in the Miyako Islands (24\% in one of these islands in 1997 [41]) [42]. The distribution of anti-HDV in the Pacific is highly heterogeneous, with reports in Nauru, Kiribati [43], Niue and Western Samoa while It is extremely low or absent in other Islands [44, 45]. In Viet Nam, in 2000-2009, 15\% of HBsAg positive people were HDV-RNA positive [46]. In Australia, Malaysia, Philippines and the Republic of Korea, HDV is uncommon in the general HBV infected population [39].

\section{Genotypes distribution and their pathogenicity}

There are at least eight HDV genotypes (1 to 8). Viral genotypic diversity is related to the geographical location (Table 2). HDV genotypes differ in terms of clinical outcomes. Genotype 1 is prevalent worldwide and has a variable course of infection. In Europe, North America and South Asia,Central and Northern Asia, eastern Mediterranian, and Middle East, genotype 1 is the most prevalent [47-57], while others are extremely rare. Genotype 1 was the most prevalent in Africa (median 88\%) [14]. Genotype 2 is mostly reported from the Yakutia region of Russia, the Taiwan province of China, and Japan [28]. It possibly derives from a common genotype 2 prototype [28]. Genotype 2 is associated with higher rate of remission than genotype 1 [58]. Genotype 3 is common in the Amazon Basin (90\% of HDV-infected people) [20], and is associated with more severe forms of the disease, earlier onset of HCC and outbreaks of fatal acute liver failure [59]. Genotype 4 is reported in the Far East and often leads to mild liver disease. However, a variant of genotype 4 on the Miyako Islands in Japan is associated with greater progression to cirrhosis than genotype 4 in the Taiwan province ofChina [60]. Genotypes 5-8 are reported in Africa and in African migrants to Europe $[14,61,62]$, but the natural history is not well characterised [14, 63, 64].

\section{Factors associated with HDV infection}

An association between prevalent HDV infection and injection drug use was reported the USA [65, 66], United Kingdom [67], and Iran [9, 12]. The high prevalence of anti-HDV in PWIDs suggests that injecting drug use is a risk factor for HDV super-infection. Sex workers also often have a higher prevalence of anti-HDV, especially if they inject drugs [68]. Migration from high HDV infection prevalence countries affects the epidemiology of the host country, explaining an increasing prevalence in France [69], Greece [70], Italy [71], Spain [72], Germany [73], and the United Kingdom [67]. In Western European countries, 55 to $95 \%$ of HDV infections are reported in more affected population groups, including PWID, and immigrants from highly endemic areas [16]. 
Table 1 Key elements regarding hepatitis D in the guidelines addressing hepatitis B

\begin{tabular}{|c|c|c|c|c|c|c|}
\hline & Epidemiology & Natural history & Screening, Diagnosis & Treatment & Management & Prognosis \\
\hline $\begin{array}{l}\text { AASL } \\
\text { D }\end{array}$ & - & - & $\begin{array}{l}\text { Anti-HDV screening is } \\
\text { recommended in HIV } \\
\text { positive persons, } \\
\text { persons who inject } \\
\text { drugs, men who have } \\
\text { sex with men, those at } \\
\text { risk for sexually } \\
\text { transmitted diseases, } \\
\text { migrants from areas of } \\
\text { high HDV endemicity, } \\
\text { patients with low HBV- } \\
\text { DNA levels and ele- } \\
\text { vated ALT levels. }\end{array}$ & $\begin{array}{l}\text { PegIFNa for } 12 \text { months } \\
\text { is the recommended } \\
\text { therapy for those with } \\
\text { elevated HDV-RNA } \\
\text { levels and ALT eleva- } \\
\text { tion. If HBV-DNA levels } \\
\text { are elevated, concur- } \\
\text { rent therapy with NA } \\
\text { is indicated. }\end{array}$ & $\begin{array}{l}\text { Assessment of } \\
\text { HDV-RNA is war- } \\
\text { ranted if ALT ele- } \\
\text { vation occurs } \\
\text { following treat- } \\
\text { ment because of } \\
\text { the high rates of } \\
\text { relapse. } \\
\text { Reasonable to } \\
\text { refer patients to } \\
\text { specialized } \\
\text { centers that offer } \\
\text { access to } \\
\text { experimental } \\
\text { therapies. }\end{array}$ & - \\
\hline EASL & - & $\begin{array}{l}\text { Severe or fulminant } \\
\text { hepatitis is more } \\
\text { frequently reported in } \\
\text { HBV-HDV co-infection } \\
\text { compared to HBV } \\
\text { mono-infection. } \\
\text { Chronic infection after } \\
\text { acute HBV-HDV hepa- }\end{array}$ & $\begin{array}{l}\text { Confirmed by } \\
\text { detectable HDV RNA, } \\
\text { immuno-histochemical } \\
\text { staining for HDV anti- } \\
\text { gen, or IgM anti-HDV. } \\
\text { However, diagnosis of } \\
\text { active HDV infection } \\
\text { may be difficult, as }\end{array}$ & $\begin{array}{l}\text { PegIFNa for at least } \\
48 \text { weeks is the current } \\
\text { treatment of choice in } \\
\text { HDV-HBV co-infected } \\
\text { patients with compen- } \\
\text { sated liver disease. It } \\
\text { can be continued irre- } \\
\text { spective of on- }\end{array}$ & $\begin{array}{l}\text { Long-term follow- } \\
\text { up HDV RNA } \\
\text { monitoring is rec- } \\
\text { ommended for all } \\
\text { treated patients } \\
\text { as long as HBsAg } \\
\text { is present. }\end{array}$ & $\begin{array}{l}\text { Persistent HDV } \\
\text { replication leads to } \\
\text { cirrhosis and HCC at } \\
\text { annual rates of } 4 \text { and } \\
2.8 \% \text {, leading to high } \\
\text { fatality rate and } \\
\text { justifying the need for } \\
\text { antiviral therapy. }\end{array}$ \\
\hline
\end{tabular}

titis is less common, HDV RNA assays are treatment response

while chronic delta not standardised and pattern if well toler-

hepatitis develops in HDV antigen and lgM ated. Patients with on70-90\% of patients anti-HDV assays are going HBV DNA

with HDV not widely available superinfection.

APAS The prevalence of HDV L $\quad$ has not declined. In the United States of America, Australia and some European countries, the prevalence of HDV infection is increasing.

Chronic infection after acute HBVHDV hepatitis is less common, while chronic hepatitis D develops in $70-90 \%$ of patients with HDV superinfection.

Confirmed by detectable HDV RNA, immuno-histochemical staining for HDV antigen, or lgM anti-HDV. But diagnosis of active HDV infection may be difficult, as HDV RNA assays are not standardized and HDV antigen and IgM antiHDV assays are not widely available.

WGO Up to $5 \%$ of the world's population is

Coinfection evolves to infected with $\mathrm{HBV}$, and probably $5 \%$ of those chronically infected with HBV have HDV infection. Some endemic areas in the developing world may have much higher prevalence. of cases, but is associated with a higher chance of fulminant acute infection, while superinfection leads to progressive disease and cirrhosis in more than $80 \%$ of cases.
Should be evaluated
particularly if hepatitis is present in the face of little or no HBV viral replication, or if they come from an HDVendemic region or have acquired HBV through injection drug use. Infection should be diagnosed by detection of HDV RNA in serum by polymerase chain reaction, or indirectly by detection of antibodies against hepatitis $D$ antigen of the $\lg G$ and $\lg M$ classes. replication, NA therapy should be considered.

Pegylated interferon is effective against HDV. Weekly injection of pegylated interferon is currently used for 12 18 months. Nucleotide analogues treatment might be considered in some patients who have active HBV replication with persistent or fluctuating serum HBV DNA levels above $2000 \mathrm{IU} / \mathrm{ml}$.

Chronic hepatitis D should be treated with IFN (preferably pegylFN) for at least 12 months, but the treatment results are suboptimal. Patients with active HBV replication despite HDV coinfection may benefit from treatment with NA in combination with PegIFN.
Patients should be monitored for 6 months post treatment and beyond.
HDV can cause severe liver injury that may result in fulminant hepatic failure and rapid progression to cirrhosis and hepatic decompensation, as well as an increased risk of liver cancer.
Cirrhosis develops at a younger age than in patients with chronic HBV monoinfection. 
Table 2 HDV genotypes and their geographical distribution

\begin{tabular}{lll}
\hline Genotype & Geographical location & Clinical features \\
\hline 1 & Europe, North America and South Asia,Central and Northern Asia, & Variable course \\
2 & eastern Mediterranian, and Middle East & \\
3 & Yakutia region (Russia), Taiwan (China), and Japan & Higher rate of remission than genotype 1 \\
4 & Amazon Basin & $\begin{array}{l}\text { More severe, earlier onset of HCC, and outbreaks of lethal } \\
\text { acute liver failure }\end{array}$ \\
5 & Miyako Island (Japan), Taiwan (China) & $\begin{array}{l}\text { Variant on the Miyako Islands associated with greater } \\
\text { progression to cirrhosis than in Taiwan }\end{array}$ \\
& Africa, Europe (migrants from Africa) & $\begin{array}{l}\text { More associated with HCC than genotype 1 and other African } \\
\text { genotypes } \\
\text { Better prognosis with fewer episodes of hepatic } \\
\text { decompensation }\end{array}$ \\
& Africa, Europe (migrants from Africa) & Few data
\end{tabular}

\section{Mortality due to HDV infection}

The International Agency for Research on Cancer estimated that in 2012, around 430,000 (56\%) of new HCC cases were attributable to HBV $[74,75]$. WHO reported that in 2015, approximately 380,000 people died of liver cancer secondary to HBV and 490,000 people died of cirrhosis due to HBV [76]. While the HDV coinfection worsens the outcomes of patients infected with HBV, very few studies estimated the proportion of HBV deaths that are also attributable to HDV infection.

\section{Testing strategies}

Among persons with HBV infection, clinical guidelines recommend testing for HDV infection in patients who migrated from high prevalence areas, in those with cirrhosis, and those who have elevated liver tests while receiving appropriate treatment for HBV infection $[8,12]$. In highly endemic areas, HBsAg positive patients may need to be tested at least once for anti-HDV. In other areas, testing may be restricted to HBsAg positive persons with abnormal ALT and low HBV DNA and those not responding well to appropriate treatment, irrespective of HBV DNA level. In terms of cancer prevention, some clinical guidelines recommend screening persons with HDV infection with ultrasonography every 6 months [8].

\section{Treatment}

The management of HDV infection has not changed in over 30 years and consists of treatment with interferon. However, new medicines have been explored for the management of HDV [16]. Furthermore, novel therapeutics that target HDV entry, prenylation and nucleic acid replication now offer a promise of more effective treatment for HDV infection [77].

\section{Standard therapies}

Pegylated interferon (PegIFN) is the only medicine mentioned as effective against HDV in the WHO guidelines
[78]. Other guidelines recommend PegIFN for at least 48 weeks irrespective of response patterns $[8,10-12,79]$. Of patients who receive PegIFN $\alpha$ for 48 weeks, $17-43 \%$ of treated patients had undetectable HDV RNA [80-83]. Sustained virological response remains uncommon, and late relapses occurred in more than $50 \%$ of responders [84]. Stopping PegIFN prematurely is not recommended if treatment is well tolerated. Late responses may occur in patients and long-term follow-up studies indicate that IFN based therapy is associated with a lower disease progression. Long-term follow-up and HDV RNA monitoring is recommended for all treated patients as long as HBsAg is present.

\section{Nucleotide analogues}

WHO recommends Nucleot(s) ide analogues (NA) for the treatment of chronic HBV infecton [2, 6]. NA do not impact HDV replication and related disease, because the virus uses host enzymes for replication and thus lacks enzyme targets. NA analogs have been tested for a duration of 6 to 18 months in chronic hepatitis D and were ineffective (NAs do not affect HBsAg synthesis, the main function needed by HDV for propagation) [85]. Tenofovir was reported to have an effect when used for longer treatment duration in HIV-HDV co-infection [86, 87], although these results have not been confirmed $[88,89]$.

\section{Nucleotide analogs in combination with interferons}

A trial compared 48 weeks pegylated interferon with or without adefovir with adefovir monotherapy $28 \%$ of patients receiving pegylated interferon with or without adefovir (compared to none on adefovir) achieved undetectable HDV-RNA level 24 weeks after completing therapy [90]. A similar effect on HBsAg levels was not reported in a follow up study, which compared PegIFNtenofovir combination with PegIFN monotherapy [91]. Adding lamivudine [92, 93], ribavirin [83, 94], adefovir [90], tenofovir [88], or entecavir [95] to PegIFN does not provide additional benefits over monotherapy. 


\section{Myrcludex B}

Myrcludex B is a hepatocyte entry inhibitor that interferes with HDV entry $[96,97]$. It reduces the population of HDV-positive cells and allows HDV-free hepatocytes to regenerate, which might ultimately lead to eradication of the virus [98]. In a phase 2a study of patients HBVDNA and HDV-RNA positive, myrcludex B led to HDV RNA decline, and 1 of 7 patients became HDV-RNA negative. Moreover, 5 of 7 patients became HDV-RNA negative in combination with PegIFN, suggesting a synergistic effect of myrcludex $B$ and PegIFN [99]. In a phase $2 \mathrm{~b}$ open label study, Myrcludex B in combination with tenofovir led to a dose-dependent HDV-RNA decline associated with clinical [100] and virological [101] improvements. However, HDV-RNA levels rebounded after Myrcludex B was discontinued [102]. Myrcludex B has been well tolerated with no dose limiting toxicity [101]. In a new phase 2 study suggested a synergistic effect of myrcludex $B$ in combination with pegylated interferon [103]. However, asymptomatic dose-dependent increases in bile acid levels were reported in study participants.

\section{Lonafarnib}

Lonafarnib is a prenylation inhibitor that inhibits virion assembly. In a phase 2 double-blinded, randomized, placebo-controlled trial, oral lonafarnib (100 mg or 200 $\mathrm{mg}$ ) twice daily for 28 days significantly reduced viremnia [104]. However, serum HBsAg levels did not change and adverse events were frequent [101]. Combining lonafanib with PegIFN achieved more substantial and rapid HDV-RNA reduction, compared to historical responses with PegIFN alone.

\section{Ritonavir}

Ritonavir (a protease inhibitor) inhibits one of the cytochrome $\mathrm{P}^{-450}$ systems that metabolizes lonafarnib, leading to higher serum levels with minimal side effects $[104,105]$. Lonafarnib plus ritonavir yielded a better antiviral response RNA after 8 weeks of therapy [102], which did not last after the therapy was discontinued [106]. However, in a subset of patients, 8 to 12 weeks of therapy with a lonafarnib based regimen, led to a posttreatment biochemical flare with subsequent normalization of ALT and undetectable viruses [104]. Tiple therapy with low dose (either $25 \mathrm{mg}$, bid or $50 \mathrm{mg}$, bid) in combination with ritonavir for 24 weeks appears synergistic [107].

\section{Nucleic acid polymers}

Nucleic acid polymers (NAPs) can lead to dramatic declines in HBsAg for HBV-HDV co-infected patients after 6 months or less. REP2139 is one of these NAPs and an inhibitor of HBsAg release. A phase 2 proof of concept trial combined REP2139 with PegIFN. Nine among 12 patients were negative at the end of treatment, 7 were negative at the end of the one-year follow-up, and 5 maintained HBsAg-suppression at the end of follow-up. Functional remission is stable at 1.5 years follow-up and is associated with persistently normal liver function and progressive reduction in median hepatic stiffness [108]. However, hematological adverse events were reported. On-treatment ALT flares may be a concern [109].

\section{Ezetimibe}

Ezetimibe inhibits NTCP and therapy with ezetimibe may lead to a decline in HDV levels. A clinical phase 2 trial is recruiting (NCT03099278).

\section{Discussion: next steps from a public health perspective \\ Epidemiology}

There is extremely high variation in HDV prevalence and genotype distribution worldwide. Prevalence is declining because of HBV immunization, but epidemiological data in many countries remain scant. Risk behaviours associated with HDV infection are also unclear. Consequently, the global HDV prevalence has been difficult to describe precisely so far and more information is necessary. From a mortality perspective, if we assume that the prevalence of HDV infection is $5-10 \%$ in the 390,000 persons who died from HBV associated HCC and in the 480,000 persons associated cirrhosis in 2015 [2], then at least 19,500-39,000 cases of HCC deaths and 24,000-48,000 cases of cirrhosis deaths could be HDV related $[76,110]$.

\section{Testing}

HDV prevalence is higher in PWID, sex workers, and migrants from highly HDV endemic countries. Thus, clinical guidelines $[5,9]$ often recommend testing in such priority populations and in high endemicity countries. However, testing approaches from a public health perspective require data on national and global epidemiology and evidence to guide how to test. While detection of anti-HDV-IgG is commonly used to test for HDV infection, HDV-RNA testing can be used to confirm infection. However, it is not widely available, and not yet standardized. Innovative methods such as point-of-care rapid diagnostic tests are not yet available. In addition, fibrosis staging of liver disease in HDV is challenging as non-invasive tests are impracticable [111]. Effective fibrosis score specifically developed for chronic HDV infection is necessary.

\section{Treatment}

Therapeutic options for HDV infection are still limited and PegIFN and NA are the only medicines mentioned 
in the most recent hepatology society guidelines $[8,10-$ 12]. However, none of these NAs affect HDV RNA replication per se. IFNs are of limited effectiveness and are associated with a high rate of relapse. New treatment strategies targeting different steps of the HDV life cycle are emerging and provide hope for the future for HDV co-infected patients. Some medicines appear more effective in combination with others, especially combined with PegIFN. Clinical trials are still ongoing and limited evidence is available. Sustained HDV suppression or cure would be necessary for sustained clinical improvement. However, since new treatments of HDV are an urgent need, experts on HDV treatment have recommended that a $2 \log$ decline of HDV RNA at end of treatment from baseline should represent a surrogate for initial treatment efficacy in clinical trials of novel therapies for patients with CHD [112].

\section{Limitations}

Our review suffers from a number of limitations. First, HDV RNA and genotype testing are not routinely done in most countries, therefore, relevant data are very limited. We therefore defined HDV infection as positive for IgG anti-HDV. Second, sampling often included potentially biased populations, such as medical outpatients or health-care workers. Finally, we summarized epidemiological data but there were insufficient data in the literature to analyse the long-term outcome of HDV infection. Long-term, multicenter prospective studies are needed to better understand the prognosis of HDV infection in different settings.

\section{Conclusion}

Our review supports three conclusions. First, while certain countries and risk/ethnic groups have very high HDV prevalence, there is a lot of heterogeneity and many data gaps. As a result, reliable global HDV prevalence estimates are unavailable. Second, testing approaches have not been defined for HDV because of a lack of diagnostic tests and insufficient evidence to determine who needs to be tested. Third, few treatment options are currently available for HDV, but none are sufficiently effective, cost effective or affordable to allow delivery on a large scale. There are three areas of work that need to be undertaken to address these gaps. First, the regional and global epidemiology need to be better characterised using systematic reviews and metaanalyses, with generation of more surveillance data at the country level. Second, we need to develop a public health testing approach for HDV, that would address who to test and how to test. Third, researchers, clinicians, academia, funding/donor institutions and governments will need to work closely with each other to make sure that treatment options identified as promising can be further evaluated and scaled for access to those infected with HDV in line with the global goal of hepatitis elimination by 2030 .

\section{Abbreviations}

Anti-HDV: Hepatitis delta virus antibody; HBV: Hepatitis B virus; HDV: Hepatitis delta virus; HCC: Hepatocellular carcinoma; PWID: Persons who inject drugs; WHO: World Health Organization; GHS: Global Health Sector Strategy; PegIFN: Pegylated interferon; NA: Nucleot(s) ide analogues

\section{Acknowledgements \\ In addition to the persons listed as authors, the staff at global hepatitis programme at $\mathrm{WHO}$ are gratefully acknowledged.}

\section{Authors' contributions}

$\mathrm{TH}$ and $\mathrm{YT}$ collected literatures and wrote the first draft of the manuscript, which was commented by all authors. YJF, HH, PE, SH, JVH, EOO, SK, CY and $M B$ reviewed the manuscript. The author(s) read and approved the final manuscript.

\section{Funding}

Dr. Yurdaydin reports personal fees from Gilead Sciences BIOPHARMA, personal fees from Abbvie and, grants from Eiger, outside the submitted work.

Availability of data and materials

All data generated or analysed during this study are included in this published article.

\section{Declarations}

Ethics approval and consent to participate

Not applicable.

\section{Consent for publication}

Not applicable.

\section{Competing interests}

Dr. Yurdaydin reports personal fees from Gilead Sciences BIOPHARMA, personal fees from Abbvie and, grants from Eiger, outside the submitted work.

\section{Author details}

${ }^{1}$ Global Hepatitis Programme, World Health Organization, Geneva, Switzerland. ${ }^{2}$ Department of Gastroenterology, Kanazawa University and WHO Collaborating Center for Chronic Hepatitis and Liver Cancer, Kanazawa, Ishikawa, Japan. ${ }^{3}$ Department of Gastroenterology, Ankara University School of Medicine, Ankara, Turkey. ${ }^{4}$ Hepatology Institute, University of Ankara, Ankara, Turkey.

Received: 21 September 2020 Accepted: 13 September 2021 Published online: 19 October 2021

\section{References}

1. Makino S, Chang MF, Shieh CK, Kamahora T, Vannier DM, Govindarajan S, et al. Molecular cloning and sequencing of a human hepatitis delta virus RNA. Nature. 1986;329(6137):343-6. https://doi.org/10.1038/329343a0.

2. World Health Organization. Global hepatitis report. Geneva: World Health Organization; 2017.

3. Farci P. Delta hepatitis: an update. J Hepatol. 2003;39:S212-9. https://doi. org/10.1016/S0168-8278(03)00331-3.

4. Rizzetto M, Hepatitis D. Virus: introduction and epidemiology. Cold Spring Harb Perspect Med. 2015;5:a021576.

5. World Health Organization. Global health sector strategy on viral hepatitis 2016-2021. Geneva: World Health Organization; 2016.

6. Chen HY, Shen DT, Ji DZ, Han PC, Zhang WM, Ma JF, et al. Prevalence and burden of hepatitis $D$ virus infection in the global population: a systematic review and meta-analysis. Gut. 2018. https://doi.org/10.1136/gutjnl-2018-31 6601. 
7. Miao Z, Zhang S, Ou X, Li S, Ma Z, Wang W, et al. Estimating the global prevalence, disease progression and clinical outcome of hepatitis delta virus infection. J Infect Dis. 2019. https://doi.org/10.1093/infdis/jiz633.

8. Terrault NA, Lok ASF, McMahon BJ, Chang KM, Hwang JP, Jonas MM, et al. Update on prevention, diagnosis, and treatment of chronic hepatitis B: AASLD 2018 hepatitis B guidance. Hepatology. 2018;67:1560-99.

9. European Association For The Study Of The Liver. EASL clinical practice guidelines: management of chronic hepatitis B virus infection. J Hepatol. 2012;57(1):167-85. https://doi.org/10.1016/j.jhep.2012.02.010.

10. European Association for the Study of the Liver; European Association for the Study of the Liver. EASL 2017 clinical practice guidelines on the management of hepatitis B virus infection. J Hepatol. 2017;67:370-98.

11. Sarin SK, Kumar M, Lau GK, Abbas Z, Chan HL, Chen CJ, et al. Asian-Pacific clinical practice guidelines on the management of hepatitis B: a 2015 update. Hepatol Int. 2016;10(1):1-98. https://doi.org/10.1007/s12072-015-9675-4.

12. Feld J, Janssen HL, Abbas Z, Elewaut A, Ferenci P, Isakov V, et al. World gastroenterology organisation global guideline hepatitis B: September 2015. J Clin Gastroenterol. 2016;50(9):691-703. https://doi.org/10.1097/MCG. 0000000000000647

13. Amini N, Alavian SM, Kabir A, Aalaei-Andabili SH, Saiedi Hosseini SY, Rizzetto M. Prevalence of hepatitis $d$ in the eastern mediterranean region: systematic review and meta analysis. Hepat Mon. 2013;13(1):e8210. https://doi.org/10. 5812/hepatmon.8210.

14. Stockdale AJ, Chaponda M, Beloukas A, Phillips RO, Matthews PC, Papadimitropoulos A, et al. Prevalence of hepatitis D virus infection in subSaharan Africa: a systematic review and meta-analysis. Lancet Glob Health. 2017;5(10):e992-e1003. https://doi.org/10.1016/S2214-109X(17)30298-X.

15. El Bouzidi K, Elamin W, Kranzer K, Irish DN, Ferns B, Kennedy P, et al. Hepatitis delta virus testing, epidemiology and management: a multicentre cross-sectional study of patients in London. J Clin Virol. 2015;66:33-7. https://doi.org/10.1016/j.jcv.2015.02.011.

16. Yurdaydin C. Recent advances in managing hepatitis D. F1000Res. 2017;6: 1596.

17. Stockdale AJ, Kreuels B, Henrion MYR, Giorgi E, Kyomuhangi I, de Martel C, et al. The global prevalence of hepatitis $D$ virus infection: systematic review and meta-analysis. J Hepatol. 2020 Sep;73(3):523-32. https://doi.org/10.1016/ j.jhep.2020.04.008.

18. World Health Organization. Hepatitis D: Fact Sheet. In: Media Centre Geneva: World Health Organization; 2017. [cited 2018 Apr 16]. Available from: http://www.who.int/mediacentre/factsheets/hepatitis-d/en/.

19. Perazzo H, Pacheco AG, Luz PM, Castro R, Hyde C, Fittipaldi J, et al. Agestandardized mortality rates related to viral hepatitis in Brazil. BMC Infect Dis. 2017;17:527. https://doi.org/10.1186/s12879-017-2619-y.

20. Crispim MA, Fraiji NA, Campello SC, Schriefer NA, Stefani MM, Kiesslich D. Molecular epidemiology of hepatitis B and hepatitis delta viruses circulating in the Western Amazon region, North Brazil. BMC Infect Dis. 2014;14:94. https://doi.org/10.1186/1471-2334-14-94

21. di Filippo VD, Cortes-Mancera F, Payares E, Montes N, de la Hoz F, Arbelaez MP, et al. Hepatitis D virus and hepatitis B virus infection in Amerindian communities of the Amazonas state, Colombia. Virol J. 2015;12:172. https:// doi.org/10.1186/s12985-015-0402-5

22. Safaie P, Razeghi S, Rouster SD, Privitera I, Sherman KE. Hepatitis D diagnostics:utilization and testing in the united states. Virus Res. 2018. https://doi.org/10.1016/j.virusres.2018.03.013 [Epub ahead of print]

23. Braga WS, de Oliveira CM, de Araújo JR, Castilho Mda C, Rocha JM, Gimaque JB, et al. Chronic HDV/HBV co-infection: predictors of disease stage---a case series of HDV-3 patients. J Hepatol. 2014;61(6):1205-11. https://doi.org/10.1 016/j.jhep.2014.05.041.

24. Khan AU, Waqar M, Akram M, Zaib M, Wasim M, Ahmad S, et al. True prevalence of twin HDV-HBV infection in Pakistan: a molecular approach. Virol J. 2011:8(1):420. https://doi.org/10.1186/1743-422X-8-420.

25. Gheorghe L, Csiki IE, lacob S, Gheorghe C, Trifan A, Grigorescu M, et al. Hepatitis delta virus infection in Romania: prevalence and risk factors. J Gastrointestin Liver Dis. 2015;24:413-21.

26. Dulger AC, Suvak B, Gonullu H, Gonullu E, Gultepe B, Aydın I, et al. High prevalence of chronic hepatitis $D$ virus infection in eastern Turkey: urbanization of the disease. Arch Med Sci. 2016;12(2):415-20. https://doi. org/10.5114/aoms.2015.52030.

27. Uzun B, Şener AG, Güngör S, Afşar I, Demirci M. Evaluation of hepatitis delta virus (HDV) infection in blood donors in western Turkey. Transfus Apher Sci. 2014:50:388-91.
28. Ivaniushina V, Radjef N, Alexeeva M, Gault E, Semenov S, Salhi M, et al. Hepatitis delta virus genotypes I and II cocirculate in an endemic area of Yakutia, Russia. J Gen Virol. 2001;82:2709-18.

29. Børresen ML, Olsen OR, Ladefoged K, McMahon BJ, Hjuler T, Panum I, et al. Hepatitis D outbreak among children in a hepatitis B hyper-endemic settlement in Greenland. J Viral Hepat. 2010;17:162-70.

30. Langer $B C$, Frösner $\mathrm{GG}$, von Brunn A. Epidemiological study of viral hepatitis types A, B, C, D and E among Inuits in West Greenland. J Viral Hepat. 1997;4: 339-49.

31. Rex KF, Krarup HB, Laurberg P, Andersen S. Population-based comparative epidemiological survey of hepatitis B, D, and C among Inuit migrated to Denmark and in high endemic Greenland. Scand J Gastroenterol. 2012;47(6): 692-701. https://doi.org/10.3109/00365521.2011.634026.

32. Rizzetto M, Ciancio A. Epidemiology of hepatitis D. Semin Liver Dis. 2012; 32(3):211-9. https://doi.org/10.1055/s-0032-1323626.

33. Zaki H, Darmstadt GL, Baten A, Ahsan CR, Saha SK. Seroepidemiology of hepatitis B and delta virus infections in Bangladesh. J Trop Pediatr. 2003;49: $371-4$.

34. Chakraborty P, Kailash U, Jain A, Goyal R, Gupta RK, Das BC, et al. Seroprevalence of hepatitis D virus in patients with hepatitis B virus-related liver diseases. Indian J Med Res. 2005;122:254-7.

35. Mulyanto, Depamede SN, Surayah K, Tsuda F, Ichiyama K, Takahashi M, et al. A nationwide molecular epidemiological study on hepatitis B virus in Indonesia: identification of two novel subgenotypes, B8 and C7. Arch Virol. 2009;154:1047-59.

36. Louisirirotchanakul S, Myint KS, Srimee B, Kanoksinsombat C, Khamboonruang C, Kunstadter $\mathrm{P}$, et al. The prevalence of viral hepatitis among the Hmong people of northern Thailand. Southeast Asian J Trop Med Public Health. 2002;33:837-44.

37. Baatarkhuu O, Uugantsetseg G, Munkh-Orshikh D, Naranzul N, Badamjav S, Tserendagva D, et al. Viral hepatitis and liver diseases in Mongolia. HepatoGastroenterol. 2017;7(1):68-72. https://doi.org/10.5005/jp-journals-10018-1215.

38. Chen X, Oidovsambuu O, Liu P, Grosely R, Elazar M, Winn VD, et al. A novel quantitative microarray antibody capture assay identifies an extremely high hepatitis delta virus prevalence among hepatitis B virus-infected mongolians. Hepatology. 2017;66(6):1739-49. https://doi.org/10.1002/hep.2 8957.

39. Abbas Z, Jafri W, Raza S. Hepatitis D: Scenario in the Asia-Pacific region. World J Gastroenterol. 2010;16:554-62. https://doi.org/10.3748/wjg.v16.i5. 554.

40. Lin HH, Lee SS, Yu ML, Chang TT, Su CW, Hu BS, et al. Changing hepatitis D virus epidemiology in a hepatitis $B$ virus endemic area with a national vaccination program. Hepatology. 2015;61:1870-9. https://doi.org/10.1002/ hep.27742.

41. Sakugawa $H$, Nakasone H, Shokita H, Kawakami Y, Nakachi N, Adaniya H, et al. Seroepidemiological study on hepatitis delta virus infection in the Irabu Islands, Okinawa, Japan. J Gastroenterol Hepatol. 1997;12(4):299-304. https://doi.org/10.1111/j.1440-1746.1997.tb00425.x.

42. Sakugawa $H$, Nakasone H, Nakayoshi T, Kawakami Y, Miyazato S, Kinjo F, et al. Hepatitis delta virus genotype Ilb predominates in an endemic area, Okinawa, Japan. J Med Virol. 1999;58:366-72.

43. Han M, Littlejohn M, Yuen L, Edwards R, Devi U, Bowden S, et al. Molecular epidemiology of hepatitis delta virus in the Western Pacific region. J Clin Virol. 2014;61(1):34-9. https://doi.org/10.1016/j.jcv.2014.05.021.

44. Dimitrakakis M, Gust I. HDV infection in the Western Pacific region. Prog Clin Biol Res. 1991;364:89-96

45. Tibbs CJ. Delta hepatitis in Kiribati: a pacific focus. J Med Virol. 1989;29(2): 130-2. https://doi.org/10.1002/jmv.1890290210.

46. Sy BT, Ratsch BA, Toan NL, le Song H, Wollboldt C, Bryniok A, et al. High prevalence and significance of hepatitis $D$ virus infection among treatmentnaïve HBsAg-positive patients in Northern Vietnam. PLoS One. 2013;8: e78094. https://doi.org/10.1371/journal.pone.0078094.

47. Saudy N, Sugauchi F, Tanaka Y, Suzuki S, Aal AA, Zaid MA, et al. Genotypes and phylogenetic characterization of hepatitis B and delta viruses in Egypt. $J$ Med Virol. 2003;70(4):529-36. https://doi.org/10.1002/jmv.10427.

48. Takahashi M, Nishizawa T, Gotanda Y, Tsuda F, Komatsu F, Kawabata T, et al. High prevalence of antibodies to hepatitis $A$ and $E$ viruses and viremia of hepatitis $B, C$, and $D$ viruses among apparently healthy populations in Mongolia. Clin Diagn Lab Immunol. 2004;11:392-8.

49. Tsatsralt-Od B, Takahashi M, Endo K, Buyankhuu O, Baatarkhuu O, Nishizawa $T$, et al. Infection with hepatitis $A, B, C$, and delta viruses among patients 
with acute hepatitis in Mongolia. J Med Virol. 2006;78(5):542-50. https://doi. org/10.1002/jmv.20574.

50. Khan A, Kurbanov F, Tanaka Y, Elkady A, Sugiyama M, Dustov A, et al. Epidemiological and clinical evaluation of hepatitis $B$, hepatitis $C$, and delta hepatitis viruses in Tajikistan. J Med Virol. 2008;80(2):268-76. https://doi. org/10.1002/jmv.21057.

51. Mohebbi SR, Zali N, Derakhshan F, Tahami A, Mashayekhi R, Amini-BavilOlyaee S, et al. Molecular epidemiology of hepatitis delta virus (HDV) in Iran: a preliminary report. J Med Virol. 2008;80(12):2092-9. https://doi.org/10.1 $002 / j m v .21326$.

52. Celik I, Karatayli E, Cevik E, Kabakçi SG, Karatayli SC, Dinç B, et al. Complete genome sequences and phylogenetic analysis of hepatitis delta viruses isolated from nine Turkish patients. Arch Virol. 2011;156:2215-20.

53. Perveen S, Nasir MI, Shahid SM, Azhar A, Khan OY. Phylogenetic analysis of HDV isolates from HBsAg positive patients in Karachi, Pakistan. Virol J. 2012; 9:162. https://doi.org/10.1186/1743-422X-9-162.

54. Bulut Y, Bahcecioglu IH, Aygun C, Oner PD, Ozercan I, Demirdag K. High genetic diversity of hepatitis delta virus in eastern Turkey. J Infect Dev Ctries. 2014:8:74-8.

55. Attaran MS, Sharifi Z, Hosseini SM, Samei S, Ataee Z. Prevalence of hepatitis $B$ and hepatitis $D$ coinfection in asymptomatic blood donors in Iran. APMIS. 2014;122(3):243-7. https://doi.org/10.1111/apm.12137.

56. Shirvani-Dastgerdi E, Amini-Bavil-Olyaee S, Alavian SM, Trautwein C, Tacke F. Comprehensive analysis of mutations in the hepatitis delta virus genome based on full-length sequencing in a nationwide cohort study and evolutionary pattern during disease progression. Clin Microbiol Infect. 2015; 21:510. e11-23. https://doi.org/10.1016/j.cmi.2014.12.008 Epub 2014 Dec 26.

57. Yacoubi L, Brichler S, Mansour W, Le Gal F, Hammami W, Sadraoui A, et al. Molecular epidemiology of hepatitis B and Delta virus strains that spread in the Mediterranean North East Coast of Tunisia. J Clin Virol. 2015;72:126-32. https://doi.org/10.1016/j.jcv.2015.10.002.

58. Su CW, Huang YH, Huo TI, Shih HH, Sheen IJ, Chen SW, et al. Genotypes and viremia of hepatitis $B$ and $D$ viruses are associated with outcomes of chronic hepatitis D patients. Gastroenterology. 2006;130(6):1625-35. https:// doi.org/10.1053/j.gastro.2006.01.035.

59. Borzacov LM, de Fiqueiredo Nicolete LD, Souza LF, Dos Santos AO, Vieira DS, Salcedo JM. Treatment of hepatitis delta virus genotype 3 infection with peg-interferon and entecavir. Int J Infect Dis. 2016;46:82-8.

60. Watanabe H, Nagayama K, Enomoto N, Chinzei R, Yamashiro T, Izumi N, et al. Chronic hepatitis delta virus infection with genotype Ilb variant is correlated with progressive liver disease. J Gen Virol. 2003;84:3275-89.

61. Le Gal F, Gault E, Ripault MP, Serpaggi J, Trinchet JC, Gordien E, et al. Eighth major clade for hepatitisdelta virus. Emerg Infect Dis. 2006;12:1447-50.

62. Radjef N, Gordien E, Ivaniushina V, Gault E, Anaïs P, Drugan T, et al. Molecular phylogenetic analyses indicate a wide and ancient radiation of African hepatitis delta virus, suggesting a deltavirus genus of at least seven major clades. J Virol. 2004;78(5):2537-44. https://doi.org/10.1128/JVI.78.5.253 7-2544.2004

63. Gerber A, Gal FL, Dziri S, Alloui C, Roulot D, Abdesselam ZB, et al. Molecular diversity of HDV strains that spread in France: a study of 2224 clinical strains prospectively collected during fifteen years. J Hepatol. 2018;68:S783.

64. Spaan M, Carey I, Bruce M, Shang D, Dusheiko G, Agarwal K. Are hepatitis delta virus (HDV) genotypes important to determine the disease progression and therapy responses? J Viral Hepat. 2018;25:S21.

65. Kucirka LM, Farzadegan H, Feld JJ, Mehta SH, Winters M, Glenn JS, et al. Prevalence, correlates, and viral dynamics of hepatitis delta among injection drug users. J Infect Dis. 2010;202:845-52.

66. Kushner T, Serper M, Kaplan DE. Delta hepatitis within the veterans affairs medical system in the United States: prevalence, risk factors, and outcomes. J Hepatol. 2015;63(3):586-92. https://doi.org/10.1016/j.jhep.2015.04.025.

67. Cross TJ, Rizzi P, Horner M, Jolly A, Hussain MJ, Smith HM, et al. The increasing prevalence of hepatitis delta virus (HDV) infection in South London. J Med Virol. 2008;80:277-82.

68. Rosenblum L, Darrow W, Witte J, Cohen J, French J, Gill PS, et al. Sexual practices in the transmission of hepatitis $B$ virus and prevalence of hepatitis delta virus infection in female prostitutes in the United States. JAMA. 1992;267(18):2477-81. https://doi.org/10.1001/jama.1992. 03480180063030 .

69. Servant-Delmas A, Le Gal F, Gallian P, Gordien E, Laperche S. Increasing prevalence of HDV/HBV infection over 15 years in France. J Clin Virol. 2014; 59(2):126-8. https://doi.org/10.1016/j.jcv.2013.11.016.
70. Manesis EK, Vourli G, Dalekos G, Vasiliadis T, Manolaki N, Hounta A, et al. Prevalence and clinical course of hepatitis delta infection in Greece: a 13year prospective study. J Hepatol. 2013;59(5):949-56. https://doi.org/10.101 6/j.jhep.2013.07.005.

71. Sagnelli E, Taliani G, Castelli F, Bartolozzi D, Cacopardo B, Armignacco O, et al. Chronic HBV infection in pregnant immigrants: a multicenter study of the Italian Society of Infectious and Tropical Diseases. New Microbiol. 2016; 39:114-8.

72. Rivas $P$, Herrero MD, Poveda E, Madejón A, Treviño A, Gutiérrez M, et al. Hepatitis B, C, and D and HIV infections among immigrants from Equatorial Guinea living in Spain. Am J Trop Med Hyg. 2013;88:789-94.

73. Wedemeyer H, Manns MP. Epidemiology, pathogenesis and management of hepatitis D: update and challenges ahead. Nat Rev Gastroenterol Hepatol. 2010;7(1):31-40. https://doi.org/10.1038/nrgastro.2009.205.

74. Plummer M, de Martel C, Vignat J, Ferlay J, Bray F, Franceschi S. Global burden of cancers attributable to infections in 2012: a synthetic analysis. Lancet Glob Health. 2016;4(9):e609-16. https://doi.org/10.1016/S2214-109X(1 6)30143-7.

75. Maucort-Boulch D, de Martel C, Franceschi S, Plummer M. Fraction and incidence of liver cancer attributable to hepatitis B and $C$ viruses worldwide. Int J Cancer. 2018;142(12):2471-7. https://doi.org/10.1002/ijc.31280.

76. World Health Organization. Summary tables of mortality estimates by cause, age and sex, globally and by region, 2000-2016. Geneva: World Health Organization; 2018. http://www.who.int/healthinfo/global_burden_disease/ en/

77. Yurdaydin C. New treatment options for delta virus: is a cure in sight? J Viral Hepat. 2019;26(6):618-26. https://doi.org/10.1111/jvh.13081.

78. World Health Organization. Guidelines for the prevention, care and treatment of persons with chronic hepatitis B infection. Geneva: World Health Organization; 2015.

79. Wranke A, Serrano BC, Heidrich B, Kirschner J, Bremer B, Lehmann P, et al. Antiviral treatment and liver-related complications in hepatitis delta. Hepatology. 2017;65(2):414-25. https://doi.org/10.1002/hep.28876

80. Erhardt A, Gerlich W, Starke C, Wend U, Donner A, Sagir A, et al. Treatment of chronic hepatitis delta with pegylated interferon-alpha2b. Liver Int. 2006; 26(7):805-10. https://doi.org/10.1111/j.1478-3231.2006.01279.x.

81. Niro GA, Ciancio A, Gaeta GB, Smedile A, Marrone A, Olivero A, et al. Pegylated interferon alpha-2b as monotherapy or in combination with ribavirin in chronic hepatitis delta. Hepatology. 2006;44(3):713-20. https:// doi.org/10.1002/hep.21296.

82. Wedemeyer H, Yurdaydin C, Dalekos GN, Erhardt A, Çakaloğlu Y, Değertekin $\mathrm{H}$, et al. Peginterferon plus adefovir versus either drug alone for hepatitis delta. N Engl J Med. 2011;364:322-31.

83. Castelnau C, Le Gal F, Ripault MP, Gordien E, Martinot-Peignoux M, Boyer N, et al. Efficacy of peginterferon alpha-2b in chronic hepatitis delta: relevance of quantitative RT-PCR for follow-up. Hepatology. 2006;44(3):728-35. https:// doi.org/10.1002/hep.21325.

84. Yilmaz B, Can G, Ucmak F, Arslan AO, Solmaz I, Unlu O, et al. Polymorphisms in the IL28B gene (rs12979860, rs8099917) and the virological response to pegylated interferon therapy in hepatitis D virus patients. Acta Gastroenterol Belg. 2016;79:206-10.

85. Yurdaydin C. Treatment of chronic delta hepatitis. Semin Liver Dis. 2012;32: 237-44

86. Sheldon J, Ramos B, Toro C, Ríos P, Martínez-Alarcón J, Bottecchia M, et al. Does treatment of hepatitis $B$ virus (HBV) infection reduce hepatitis delta virus (HDV) replication in HIV-HBV-HDV-coinfected patients? Antivir Ther. 2008;13:97-102

87. Fernández-Montero JV, Vispo E, Barreiro P, Sierra-Enguita R, de Mendoza C, Labarga $P$, et al. Hepatitis delta is a major determinant of liver decompensation events and death in HIV-infected patients. Clin Infect Dis. 2014:58:1549-53.

88. Boyd A, Miailhes P, Brichler S, Scholtès C, Maylin S, Delaugerre C, et al. Effect of tenofovir with and without interferon on hepatitis $D$ virus replication in HIV-hepatitis B virus-hepatitis D virus-infected patients. AIDS Res Hum Retrovir. 2013;29(12):1535-40. https://doi.org/10.1089/a id.2013.0008.

89. Béguelin C, Friolet N, Moradpour D, Sahli R, Suter-Riniker F, Lüthi A, et al. Impact of tenofovir on hepatitis delta virus replication in the Swiss human immunodeficiency virus cohort study. Clin Infect Dis. 2017;64:1275-8.

90. Wranke A, Yurdaydin C, Heidrich B, Kalliopi Z, Yalcin K, Fehmi Z, et al. A virological response to PEG-IFNa treatment of hepatitis delta is associated 
with an improved clinical long-term outcome: 10 years follow-up of the HIDIT-1 study. J Hepatol. 2018:68:FS507.

91. Wedemeyer H, Yurdaydin C, Ernst S, Caruntu FA, Curescu MG, Kendal YK, et al. 96 weeks of pegylated-Interferonalpha-2a plus tenofovir or placebo for the treatment of hepatitis delta: the HIDIT-2 study. Hepatology. 2013;58: 222A-3A.

92. Canbakan B, Senturk H, Tabak F, Akdogan M, Tahan V, Mert A, et al. Efficacy of interferon alpha-2b and lamivudine combination treatment in comparison to interferon alpha-2b alone in chronic delta hepatitis: $a$ randomized trial. J Gastroenterol Hepatol. 2006;21(4):657-63. https://doi. org/10.1111/j.1440-1746.2006.04082.x.

93. Yurdaydin C, Bozkaya H, Onder FO, Sentürk H, Karaaslan H, Akdoğan M, et al. Treatment of chronic delta hepatitis with lamivudine vs lamivudine + interferon vs interferon. J Viral Hepat. 2008;15(4):314-21. https://doi.org/1 0.1111/j.1365-2893.2007.00936.x.

94. Gunsar F, Akarca US, Ersoz G, Kobak AC, Karasu Z, Yuce G, et al. Two-year interferon therapy with or without ribavirin in chronic delta hepatitis. Antivir Ther. 2005;10(6):721-6.

95. Abbas Z, Memon MS, Umer MA, Abbas M, Shazi L. Co-treatment with pegylated interferon alfa-2a and entecavir for hepatitis D: A randomized trial. World J Hepatol. 2016:8:625-31.

96. Soriano V, Sherman KE, Barreiro P. Hepatitis delta and HIV infection. AIDS. 2017;31(7):875-84. https://doi.org/10.1097/QAD.0000000000001424.

97. Yan $H$, Zhong G, Xu G, He W, Jing Z, Gao Z, et al. Sodium taurocholate cotransporting polypeptide is a functional receptor for human hepatitis $\mathrm{B}$ and D virus. Elife. 2012;1:e0049. https://doi.org/10.7554/eLife.00049.

98. Rizzetto M. Targeting hepatitis D. Semin Liver Dis. 2018;38(01):66-72. https:// doi.org/10.1055/s-0037-1621711.

99. Bogomolov P, Alexandrov A, Voronkova N, Macievich M, Kokina K, Petrachenkova M, et al. Treatment of chronic hepatitis D with the entry inhibitor myrcludex B: first results of a phase lb/lla study. J Hepatol. 2016; 65(3):490-8. https://doi.org/10.1016/j.jhep.2016.04.016.

100. Wedemeyer H, Bogomolov P, Blank A, Allweiss L, Dandri-Petersen M, Bremer $B$, et al. Final results of a multicenter, open-label phase $2 b$ clinical trial to assess safety and efficacy of Myrcludex B in combination with Tenofovir in patients with chronic HBV/HDV co-infection. J Hepatol. 2018:68:S3.

101. Allweiss L, Dettmer C, Volz T, Giersch K, Alexandrov A, Wedemeyer H, et al. Strong intrahepatic decline of hepatitis D virus RNA and antigen after 24 weeks of treatment with Myrcludex B in combinationwith Tenofovir in chronic HBV/HDV infected patients: interim results from a multicenter, open-label phase 2b clinical trial. J Hepatol. 2018;68:S90. https://doi.org/10.1 016/50168-8278(18)30398-2.

102. Yurdaydin C, Idilman R, Kalkan C, Karakaya F, Kartal AC, Keskin O, et al. Exploring optimal dosing of Lonafarnib with ritonavir for the treatment of chronic delta hepatitis-interim results from the lowr HDV-2 study. Hepatology. 2016;64:910A.

103. Wedemeyer H, Katrin Schöneweis K, Bogomolov PO, Voronkova NV Chulanov V, Stepanova T, et al. Interim results of a multicentre, open-label phase 2 clinical trial (MYR203) to assess safety and efficacy of myrcludex B in combination with peg-interferon alpha $2 a$ in patients with chronic HBV/ HDV co-infection. Hepatology. 2018;68:16A.

104. Koh C, Canini L, Dahari H, Zhao X, Uprichard SL, Haynes-Williams V, et al. Oral prenylation inhibition with lonafarnib in chronic hepatitis $D$ infection: a proof-of-concept randomised, double-blind, placebo-controlled phase 2A trial. Lancet Infect Dis. 2015;15:1167-74.

105. Ghosal A, Chowdhury SK, Tong W, Hapangama N, Yuan Y, Su AD, et al. Identification of human liver cytochrome P450 enzymes responsible for the metabolism of lonafarnib (Sarasar). Drug Metab Dispos. 2006;34(4):628-35. https://doi.org/10.1124/dmd.105.007906.

106. Wedemeyer H, Port K, Deterding K, Wranke A, Kirschner J, Martins EB, et al. A phase 2 study of titrating dose lonafarnib plus ritonavir in patients with chronic hepatitis D: interim results from the lonafarnib with ritonavir in HDV-4 study. AASLD Hepatol. 2016;64(1):121A. https://doi.org/10.1016/S01 68-8278(17)30310-0.

107. Yurdaydin C, Kalkan C, Karakaya F, Caliskan A, Karatayli S, Keskin O, et al. Subanalysis of the LOWR HDV-2 study reveals high response rates to Lonafarnib in patients with low viral loads. J Hepatol. 2018;68:S89. https:// doi.org/10.1016/S0168-8278(18)30397-0.

108. Bazinet M, Pantea V, Cebotarescu V, Cojuhari L, Jimbei P, Vaillant A. Establishment of persistent functional remission of HBV and HDV infection following REP 2139 and pegylated interferon alpha 2a therapy in patients with chronic HBV/HDV co-infection: 18 month follow-up results from the REP 301-LTF study. J Hepatol. 2018;68:S509. https://doi.org/10.1016/S0168-82 78(18)31266-2.

109. Bazinet M, Pântea V, Cebotarescu V, Cojuhari L, Jimbei P, Albrecht J, et al. Safety and efficacy of REP2139 and pegylated interferon alfa-2a for treatment-naive patients with chronic hepatitis $B$ virus and hepatitis $D$ virus co-infection (REP 301 and REP 301-LTF): a non-randomised, open-label, phase 2 trial. Lancet Gastroenterol Hepatol. 2017;2:877-89.

110. Farci P, Niro GA. Clinical features of hepatitis D. Semin Liver Dis. 2012;32: $228-36$.

111. Lutterkort GL, Wranke A, Yurdaydin C, Budde E, Westphal M, Lichtinghagen $\mathrm{R}$, et al. Non-invasive fibrosis score for hepatitis delta. Liver Int. 2017;37(2): 196-204. https://doi.org/10.1111/liv.13205.

112. Yurdaydin C, Abbas Z, Buti M, Cornberg M, Esteban R, Etzion O, et al. Treating chronic hepatitis delta: the need for surrogate markers of treatment efficacy. J Hepatol. 2019;70(5):1008-15. https://doi.org/10.1016/j. jhep.2018.12.022.

\section{Publisher's Note}

Springer Nature remains neutral with regard to jurisdictional claims in published maps and institutional affiliations.

Ready to submit your research? Choose BMC and benefit from:

- fast, convenient online submission

- thorough peer review by experienced researchers in your field

- rapid publication on acceptance

- support for research data, including large and complex data types

- gold Open Access which fosters wider collaboration and increased citations

- maximum visibility for your research: over $100 \mathrm{M}$ website views per year

At BMC, research is always in progress.

Learn more biomedcentral.com/submissions 